International Journal of Life Sciences
Available online at www.sciencescholar.us
Vol. 4 No. 2, August 2020, pages: $9-19$
e-ISSN: 2550-6986, p-ISSN: $2550-6994$
https://doi.org/10.29332/ijls.v4n2.428

\title{
Morphometric Variations of Rasbora Lateristriata Bleeker Population in Different Habitat: Based on Truss Character Analysis
}

\author{
Sang Ayu Made Putri Suryania ${ }^{\text {, I Gede Putu Wirawan }}{ }^{\mathrm{b}}$, Rindang Dwiyanic, Made Sritamin $^{\mathrm{d}}$
}

Manuscript submitted: 09 April 2020, Manuscript revised: 27 May 2020, Accepted for publication: 18 June 2020

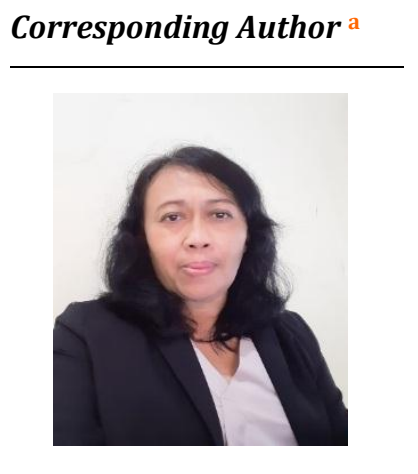

Keywords

morphometric variations;

Rasbora lateristriata;

truss network;

discriminant function

analysis;

\begin{abstract}
Rasbora lateristriata is an alternative source of protein for the people around the river and fish consumption in Indonesia. Rasbora lateristriata also an economically fish in the streams so that people make it a prime target of the catch. Rasbora lateristriata, Bleeker called yellow Rasbora is a genus of freshwater fish from the family of Cyprinidae and is often found living in groups based on small rivers with a temperature range between $22-24^{\circ} \mathrm{C}, \mathrm{pH} 6.0-6.5$. The purpose of this study was to determine the method Truss morphometric variation in the upstream, branch, middle and downstream and analyze the effects of water quality to morphometric character of Rasbora lateristriata population as scientific information in the conservation of fish. Morphometric variation of $R$. lateristriata based on Truss morphometric characters found their closeness between the four populations character of $R$ lateristriata with the degree of similarity that upstream populations with $100 \%$ similarity, branch with $60 \%$ similarity, middle and downstream with $75 \%$. Morphometric similarity value of $R$. lateristriata in the Sungi river area of 77.5\%. Morphometric value in all habitats close to $80 \%$, which means $R$, lateristriata have the same shape on the branch, middle, and downstream, while the upstream population does not have a body shape similarities with the other groups to make a subpopulation.
\end{abstract}

International Journal of Life Sciences (C) 2020.

This is an open access article under the CC BY-NC-ND license (https://creativecommons.org/licenses/by-nc-nd/4.0/).

\footnotetext{
a Program Study Doctoral (S3) of Agricultural Sciences, Agriculture Faculty, Udayana University, Denpasar, Indonesia

b Udayana University, Denpasar, Indonesia

c Udayana University, Denpasar, Indonesia

${ }^{d}$ Udayana University, Denpasar, Indonesia
} 


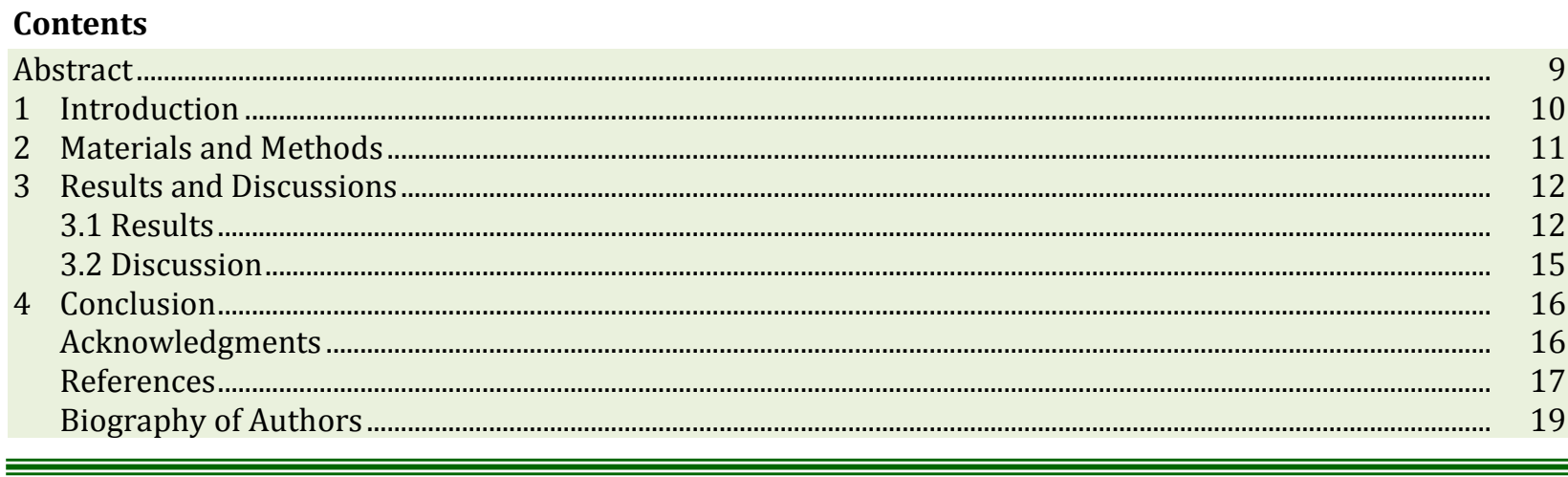

\section{Introduction}

Rasbora found in the upstream and midstream areas but is extremely rare in the downstream areas and estuaries. These fish usually live at depths of less than 1 meter (Ahmad \& Novrizal, 2011). Rasbora fish is a fish that lives clustered or schooling fish (Dina et al., 2011). The upstream of the area enter the ingredients of organic and inorganic derived from land and surrounding vegetation. The middle of the river is a transport zone which distributes organic material on to downstream water bodies. While the downstream is central to deposit organic and inorganic materials that are stored in the bottom waters and places composed (Vannote et al., 1980). The structure of Rasbora lateristriata fish populations in the Sungi river varies from upstream to downstream. At the upstream, Sungi river has a population structure of Rasbora lateristriata is low compared to the middle and downstream. This was due to the upstream availability of feed for Rasbora lateristriata very low compared to the middle and downstream where the abundance of plankton, namely 51366 ind / l (Upstream), 264168 ind / l (Middle), 139422 ind / l (Branch), and 403490 ind / l (Downstream), (Suryani et al., 2019). One species have a longitudinal distribution of the river is a reflection of the adaptation of species to changes in environmental factors (Townsend, 1980). Environmental factors affecting the distribution of fish longitudinal is physical and chemical factors. Water quality of rivers in Indonesia are mostly in contaminated conditions, especially after passing through residential areas, industrial and agricultural (Simon \& Hidayat, 2008). Domestic activities, agriculture, and industry will influence and impact the water quality conditions of the river mainly domestic activities that provide the greatest BOD concentration. A river can decrease the quality of water if the water cannot be used water quality status. Water quality status is the water quality level conditions showed blackened condition or good conditions at a water source in a given time by comparing with water quality standards. Determination of the status of water quality can use Pollution Index Method. Pollution Index (Air Pollution Index) used to determine the contamination level relative to water quality parameters (KLH Tabanan, 2010).

Sungi river is one of the ten rivers that deteriorated due to contamination by sewage (BLH Bali, 2009). Pollutant parameters that have exceeded the quality standard that is BOD, COD, Total Phosphate, Total coliform and faecal coliform where conditions are important to note because Sungi River is a drawing point for drinking water at Tabanan Regency (BLH Bali, 2009). Activities at Sungi River are dominated by agricultural activities, settlements, farms in household, and industrial-scale contained in the downstream areas. Waste from these activities led to the deterioration of water quality can be shown as an increase in the content of BOD, COD, total coliform, and faecal coliform (Peralta et al., 2005; Garat et al., 2018; Ayala et al., 2011). Increased content of this occurs in the middle of the river and decreases in the downstream areas. The quality status of Sungi River on the upstream still water quality grade 1 , while the middle and lower reaches relatively lightly polluted. Water quality parameters exceed water quality grade 1 in the Sungi River are Total Phosphate $0,55 \mathrm{mg} / \mathrm{l}$ to the middle, $0.61 \mathrm{mg} / \mathrm{l}$ downstream, and faecal coliform with an average value of 280/100 ml at the middle and 200/100 ml at the downstream (Setiari et al., 2012). 


\section{Materials and Methods}

\section{Location sampling}

Sungi river basin is divided into four, namely upstream, branch, middle, and downstream. At the upstream at point $8^{\circ} 21^{\prime} 4$ "S $115^{\circ} 10^{\prime} 49^{\prime \prime} \mathrm{E}$, on the branch $8^{\circ} 22^{\prime} 25^{\prime \prime S} 115^{\circ} 11^{\prime} 5^{\prime \prime} \mathrm{E}$ ), the middle at the point $8^{\circ} 33^{\prime} 695^{\prime S} \mathrm{~S}-$ $115^{\circ} 09^{\prime} 538$ "E and downstream at the point $8^{\circ} 3^{\prime} 053^{\prime \prime} \mathrm{S}-115^{\circ} 06^{\prime} 068$ "E.

\section{Water and fish sampling}

The sample bottle is used to take water samples to be analyzed in the analytical laboratory at Udayana University as TDS, TSS, BOD, COD, CO2, Phosphate, Amonium, Nitrate, Nitrite and phytoplankton. Some parameters such as temperature, DO and pH in the direct analysis of research sites are on the upstream side, branches, midstream, and downstream. Water sampling using the combined sample (composite sample) to obtain samples as homogeneous as possible so that samples can represent the true environmental quality, and stored at $20^{\circ} \mathrm{C}$ before analyzed in the laboratory. Fish samples were collected on the upstream, branch, middle and downstream of the Sungi River using nets stocking 3 pieces mesh with each $1.25 \times 1.25 \mathrm{~cm} ; 1 \times 1 \mathrm{~cm}$; and $0.5 \times 0.5 \mathrm{~cm}$. as many as 15 tails for each location that is used for observation of color, the distribution of pigmentation, so that a total of 80 morphometric characters tail (Kusuma et al., 2016). Morphometric characters Rasbora lateristriata fish population in the river Sungi with Truss morphometric method with measurement points are observed as shown in Table 1.

Table 1

Description of truss morphometric characters used

\begin{tabular}{llll}
\hline No. & Code & Landmark & Description \\
\hline 1. & A1 & $1-2$ & Front nose tip to the base of the dorsal fin \\
2 & B1 & $2-3$ & Dorsal fin base to the tip of the dorsal fin /rear \\
3 & C1 & $3-4$ & The tip of the dorsal fin to the beginning of the tail fin \\
4 & D1 & $4-5$ & Top to the bottom tail fin \\
5 & E1 & $5-6$ & Bottom of the dorsal fin to the tip of the anal fin \\
6 & F1 & $6-7$ & Anal fin until the beginning of pelvic fin \\
7 & G1 & $7-8$ & Pelvic fins pectoral fin to the starting point \\
8 & H1 & $8-1$ & Pectoral fin until the end of the muzzle nose \\
9 & I2 & $2-7$ & Dorsal fin to the starting point pelvic fin \\
10 & J2 & $2-6$ & Dorsal fin to the starting point of the anal fin \\
11 & K2 & $3-7$ & Dorsal fin to the starting point pelvic fin \\
12 & L2 & $3-6$ & Dorsal fin to the starting point of the anal fin \\
13 & M2 & $3-5$ & Dorsal fin to the caudal fin starting point \\
14 & N2 & $4-6$ & On the initial point through the end of the caudal fin anal \\
15 & O2 & $5-7$ & Tail fin to the tip of the anal fin
\end{tabular}

\section{Data analysis}

Analysis of the morphometric characters performed by one-way ANOVA to test differences among species for each character and then followed by multivariate data analysis. Discriminant Function Analysis (DFA) using SPSS version 20 and presented in canonical discriminant diagrams and dendrogram (Patil \& Mody, 2005; Roser \& Korsch, 1988; Mundry \& Sommer, 2007).

Suryani, S. A. M. P., Wirawan, I. G. P., Dwiyani, R., \& Sritamin, M. (2020). Morphometric variations of rasbora lateristriata bleeker population in different habitat: based on truss character analysis. International Journal of Life Sciences, 4(2), 9-18. https://doi.org/10.29332/ijls.v4n2.428 


\section{Results and Discussions}

\subsection{Results}

In this study using measurements with Truss morphometric methods (Table 1). The result's morphometric character can be used as an identifying characteristic fish taxonomy. Each species has different absolute sizes are influenced by age, gender, and the environment. The results of the comparison measurement of morphometric characters in Table 2. In the table, it can be seen that the average results morphometric measurements highest in the branch on the whole character group that is A1, B1.C1, D1, E1, F1, G1, H1, I2, J2, $\mathrm{K} 2$, L2, M2, N2, and 02. The one way ANOVA test showed that all truss character was significantly different at $95 \%$ of confident level the four groups except E1 is non significantly (Table. 3).

Table 2

The mean character value of a truss network character

\begin{tabular}{llllll}
\hline Characters & Average & Upstream & Middlestream & Branch & Downstream \\
\hline A1 & $2.95 \pm 0: 45$ & $2.87 \pm 0: 56$ & $2.60 \pm 0: 39$ & $3: 38 \pm 0: 44$ & $2.94 \pm 0: 40$ \\
B1 & $0.64 \pm 0: 11$ & $0.60 \pm 0: 13$ & $0: 52 \pm 0: 08$ & $0.74 \pm 0: 11$ & $0.68 \pm 0: 10$ \\
C1 & $2: 02 \pm 0: 35$ & $1.94 \pm 0: 45$ & $1.89 \pm 0: 32$ & $2: 26 \pm 0: 26$ & $2: 03 \pm 0: 34$ \\
D1 & $0.78 \pm 0: 17$ & $0.73 \pm 0: 17$ & $0.69 \pm 0: 09$ & $0.88 \pm 0: 11$ & $0.82 \pm 0: 27$ \\
E1 & $1: 21 \pm 0: 17$ & $1: 11 \pm 0: 29$ & $1: 18 \pm 0: 21$ & $1: 29 \pm 0: 18$ & $1: 25 \pm 0: 25$ \\
F1 & $1: 50 \pm 0: 26$ & $1: 47 \pm 0: 31$ & $1: 28 \pm 0: 23$ & $1.70 \pm 0: 27$ & $1: 54 \pm 0: 21$ \\
G1 & $1: 44 \pm 0: 31$ & $0: 18 \pm 0: 42$ & $1: 20 \pm 0: 18$ & $1.62 \pm 0: 26$ & $1: 51 \pm 0: 33$ \\
H1 & $1.72 \pm 0: 29$ & $1.65 \pm 0: 32$ & $1: 51 \pm 0: 22$ & $1.96 \pm 0: 21$ & $1.76 \pm 0: 36$ \\
I2 & $1.99 \pm 0: 34$ & $1.92 \pm 0: 42$ & $1.74 \pm 0: 26$ & $2: 30 \pm 0: 29$ & $2: 02 \pm 0: 35$ \\
J2 & $1: 48 \pm 0: 23$ & $1: 45 \pm 0: 30$ & $1: 30 \pm 0: 18$ & $1.70 \pm 0: 21$ & $1: 49 \pm 0: 18$ \\
K2 & $1.81 \pm 0: 27$ & $1.75 \pm 0: 37$ & $1: 58 \pm 0: 20$ & $2: 06 \pm 0: 23$ & $1.85 \pm 0: 25$ \\
L2 & $1: 50 \pm 0: 24$ & $1: 49 \pm 0: 30$ & $1: 35 \pm 0: 19$ & $1.69 \pm 0: 26$ & $1: 46 \pm 0: 19$ \\
M2 & $1: 33 \pm 0: 20$ & $1: 34 \pm 0: 28$ & $1: 17 \pm 0: 15$ & $1: 50 \pm 0: 17$ & $1: 30 \pm 0: 17$ \\
N2 & $2: 20 \pm 0: 37$ & $2: 09 \pm 0: 47$ & $2: 07 \pm 0: 32$ & $2: 44 \pm 0: 28$ & $2: 20 \pm 0: 38$ \\
02 & $1.61 \pm 0: 25$ & $1: 38 \pm 0: 28$ & $2: 08 \pm 0: 32$ & $1: 58 \pm 0: 19$ & $1: 42 \pm 0: 20$ \\
\hline
\end{tabular}

Table 3

The similarity of the test group mean on location

\begin{tabular}{llllll}
\hline Character & Wilks' Lambda & F & DF1 & DF2 & Sig. \\
\hline A1 & .712 & 10258 & 3 & 76 & .000 \\
B1 & .627 & 15,062 & 3 & 76 & .000 \\
C1 & .841 & 4806 & 3 & 76 & .004 \\
D1 & .847 & 4,582 & 3 & 76 & .005 \\
E1 & .920 & 2,197 & 3 & 76 & .095 \\
F1 & .737 & 9,025 & 3 & 76 & .000 \\
G1 & .793 & 6602 & 3 & 76 & .001 \\
H1 & .743 & 8775 & 3 & 76 & .000 \\
I2 & .721 & 9782 & 3 & 76 & .000 \\
J2 & .697 & 10988 & 3 & 76 & .000 \\
K2 & .697 & 10992 & 3 & 76 & .000 \\
L2 & .789 & 6,767 & 3 & 76 & .000 \\
M2 & .732 & 9267 & 3 & 76 & .000 \\
N2 & .855 & 4,313 & 3 & 76 & .007 \\
O2 & .439 & 32343 & 3 & 76 & .000 \\
\hline
\end{tabular}


The results of the analysis Discriminant Function Analysis (DFA) generated three functions. Function 1 scored eigenvalues mostly of the functions 2 and 3 . So the function of 1 to 3 has a significant role in the discrimination of four group locations. Function 1 with 9.405 eigenvalues explained $88.4 \%$ of the total variance, function 2 with 0.841 eigenvalues explain $7.9 \%$ of the total variance, and function 3 with 0.390 eigenvalues explain $3.7 \%$ of the total variance. No character contributes to function 1. Characters are a contribution to the second function is 02, B1, A2, A1, I2, K2, H1, N2, C1, D1, F1, E1, and G1. Characters that contribute to function 3 is M2 and L2 (Table 4).

Table 4

Eigenvalue, the total variance, and canonical correlation Truss morphometric characters

\begin{tabular}{|c|c|c|c|}
\hline Function & 1 & 2 & 3 \\
\hline Eigenvalue & 9.405 & 0.841 & 0.39 \\
\hline$\%$ Of Variance & 88.4 & 7.9 & 3.7 \\
\hline Canonical Correlation & 0.951 & 0.676 & .530 \\
\hline 02 & -.343 & $.450 *$ & -.084 \\
\hline B1 & .216 & $.428 *$ & .082 \\
\hline $\mathrm{J} 2$ & .172 & $.398 *$ & -.241 \\
\hline A1 & .163 & $.398 *$ & -.243 \\
\hline I2 & .162 & $.393 *$ & -.163 \\
\hline K2 & .179 & $.389 *$ & -.121 \\
\hline H1 & .152 & $.386 *$ & -.082 \\
\hline N2 & .083 & $.349 *$ & -.094 \\
\hline $\mathrm{C} 1$ & .101 & $.325 *$ & -.116 \\
\hline D1 & .106 & $.295 *$ & .060 \\
\hline F1 & .172 & $.295 *$ & -.098 \\
\hline E1 & .030 & $.282 *$ & .169 \\
\hline G1 & .159 & $.164 *$ & -.031 \\
\hline M2 & .160 & .288 & $-.380 *$ \\
\hline L2 & .127 & .300 & $-.324 *$ \\
\hline
\end{tabular}

A Scatter plot of the first three canonical discriminant functions accounted for $88.4 \%$ of the total variation and managed to describe the specimen distribution among the population although distribution is formed showing the separation of the population that is not perfect because there is cone specimen overlap between populations (Figure 1).

Suryani, S. A. M. P., Wirawan, I. G. P., Dwiyani, R., \& Sritamin, M. (2020). Morphometric variations of rasbora lateristriata bleeker population in different habitat: based on truss character analysis. International Journal of Life Sciences, 4(2), 9-18. https://doi.org/10.29332/ijls.v4n2.428 


\section{Scatterplot of SC1 vs SC2}

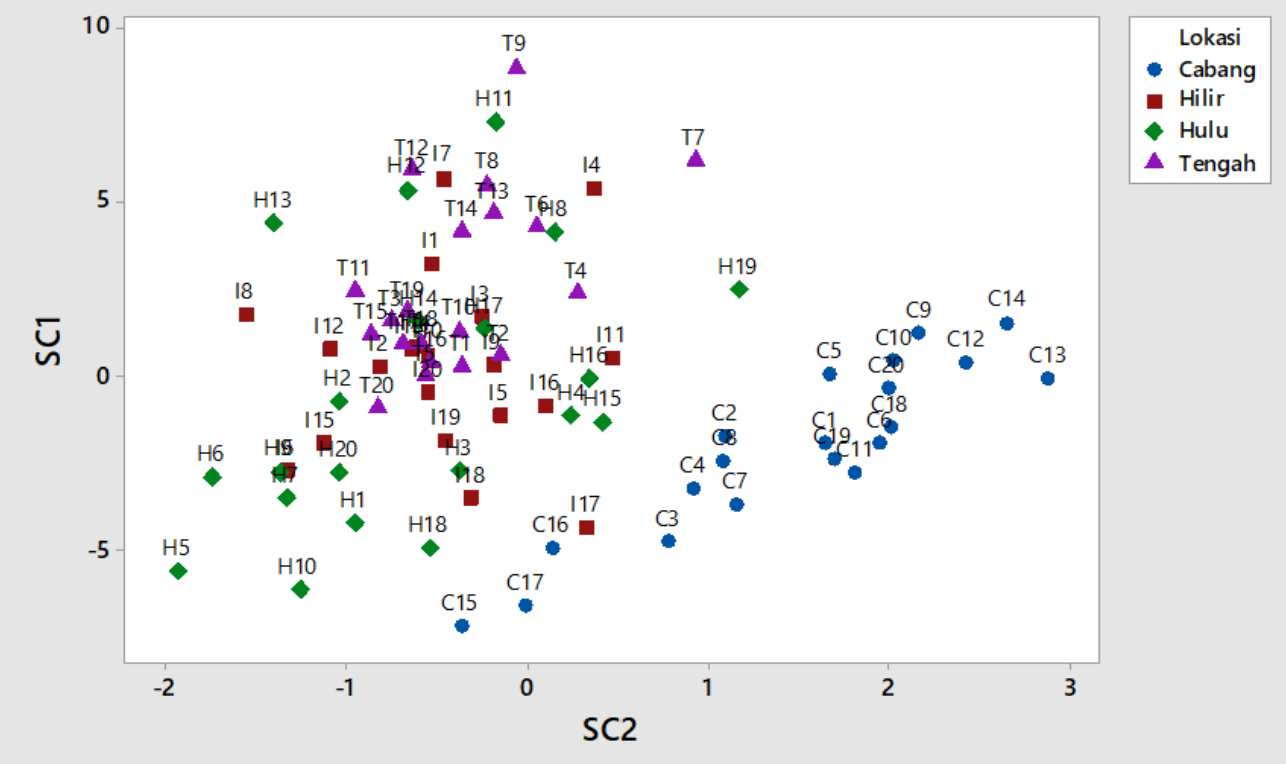

Figure 1. The main components scatter diagram 1 and 2 at the location group Rasbora lateristriata population uses 15 characters truss morphometric

Distribution of morphometric characters Rasbora lateristriata in upstream, branch, midstream and downstream has a character adjacent to each other to have a very close genetic relationship and still be in the population (Figure 1). Scatter plot function 1 vs function 2 shows 4 th location group successfully into 2 groups of fish apart (Figure 1) where the function 1 has discriminant/group the first group to the right (positive correlation) that the group branch here explained that the group branches have similarities the other group because they show a separation of the population is not perfect. After all, it still looks overlap specimens among populations. On the negative correlation (left) there are three groups, namely the upstream, midstream, and downstream. Because of the character of the upstream, midstream, and downstream, which is close to it can be concluded that the three groups of these fishes almost have the same morphometric characters.

Table 5

Values phenotype similarities within and between groups based on morphometric characters

\begin{tabular}{llllllll}
\hline \multirow{2}{*}{ Group } & & \multicolumn{5}{c}{ Predicted Group Membership } & \multirow{2}{*}{ Total } \\
\cline { 3 - 7 } & & 1 & 2 & 3 & 4 & \\
\hline Original & Count & 1 (Upstream) & 20 & 0 & 0 & 0 & 20 \\
& & 2 (Middle) & 0 & 15 & 3 & 2 & 20 \\
& 3 (Branch) & 0 & 6 & 12 & 2 & 20 \\
& 4 (Downst) & 0 & 4 & 1 & 15 & 20 \\
& 1 (Upstream) & 100.0 & .0 & .0 & .0 & 100.0 \\
& 2 (Middle) & .0 & 75.0 & 15.0 & 10.0 & 100.0 \\
& 3 (Branch) & .0 & 30.0 & 60.0 & 10.0 & 100.0 \\
& 4 (Downst) & .0 & 20.0 & 5.0 & 75.0 & 100.0 \\
\hline
\end{tabular}

a. $77.5 \%$ of original grouped cases classified Correctly

Viewing picture distribution area code morphometric Rasbora lateristriata upstream, branch, midstream and downstream (Table 5) obtained value of the same character in a group with other groups as follows: Group 1 (upstream) the value of the same character morphometric by 100\%, Group 2 (Middle) morphometric characters similarity value is $75 \%, 15 \%$ have the same character with group 3 (Branch) and $10 \%$ have the same character 
with group 4 (Downstream). Group 3 (Branch) has the same character $60 \%$ while $30 \%$ have the same character with group 2 (middle) and 10\% similarity morphometric characters with Group 4 (downstream). Group 4 (downstream) has the same character $75 \%$ while $20 \%$ have the same character with group 2 (middle) and $5 \%$ had a degree of similarity with group 3 (branch).

Cluster analysis is used to clarify population groupings resulting from the discriminant analysis. The results of cluster analysis using Euclidean distance showed that Rasbora lateeristriata from four populations namely upstream, branch, middle, and downstream cluster into 3 main clusters. Cluster one grouping between upstream and downstream, the second cluster is a branch group and the third cluster is the middle group (Figure 2).

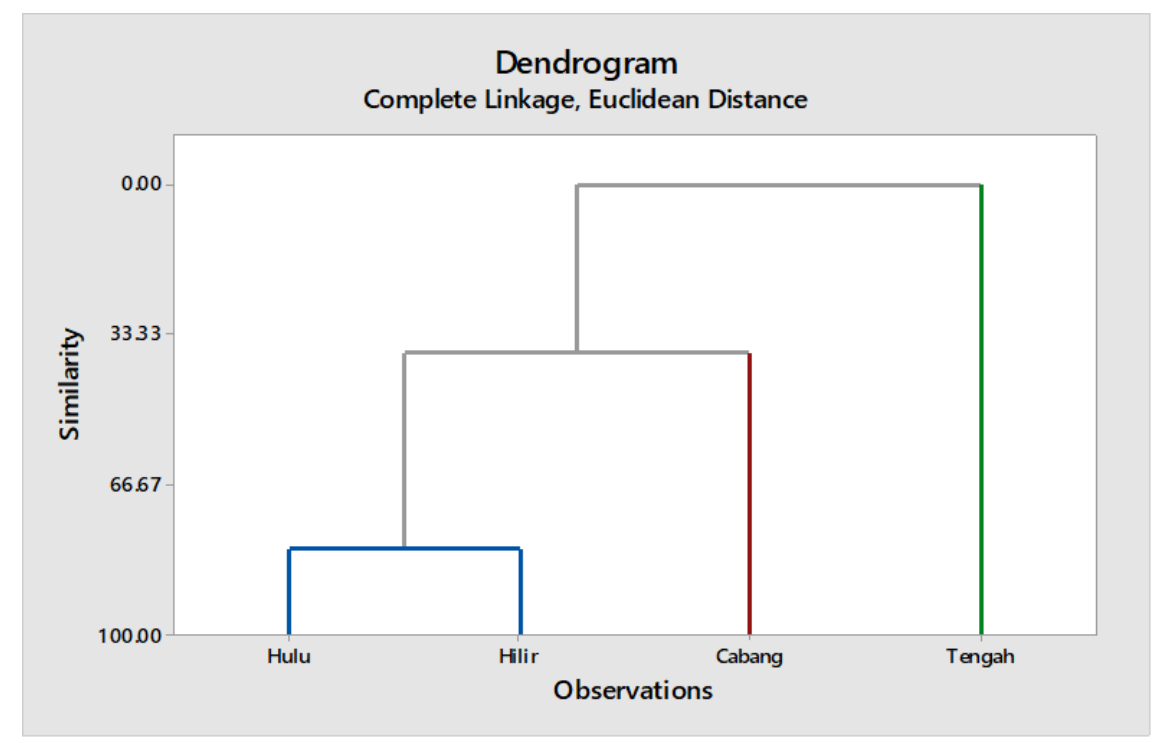

Figure 2. Dendogram of four Rasbora lateristriata populations based on morphometric variation

\subsection{Discussion}

The morphometric similarity value of Rasbora lateristriata has a value of close to $80 \%$, which is $77.5 \%$ due to environmental influences and there is a tendency for the similarity of shapes of some Rasbora lateristriata fish in groups 2, 3 and 4. The only group 1 do not have the same body shape as the other groups, causing subpopulation formation. The morphometric distribution of individual Rasbora lateristriata fish showed that the differences in the growth of the fish studied were not far between each other in the morphometric distribution. Based on the results of the analysis of the main components, a dendrogram can be made which groups Rasbora lateristriata based on the level of morphometric similarity between populations (Figure 2). Based on the dendrogram grouping above Rasbora latersitriata population in the upstream has a relatively high similarity with the Rasbora lateristriata population in the downstream and is relatively different from the Rasbora lateristriata population in the branch and middle. Analysis of grouping using a dendrogram is consistent with the results of the scatter diagram analysis. The relatively high similarity in the upstream and downstream can be caused by the population of Rasbora lateristriata in the downstream which has environmental conditions such as temperature, BOD, TSS, Ammonia, Phosphate which exceeds the quality standard can morphometrically adapt from the water quality exposure. The upstream temperature is still following the Rasbora lateristriata habitat, but adaptation also occurs due to the very low of phytoplankton. In addition to genetic factors, morphometric diversity is also caused by several factors such as differences in environmental conditions, topography, and different habitats (Hossain et al. 2010; Solomon et al. 2015; Sidik et al. 2016). Increased water temperatures can affect fish behavior such as decreased food behavior even though natural food is available. In upstream the phytoplankton are low but the temperature is following the life of Rasbora lateristriata.

Suryani, S. A. M. P., Wirawan, I. G. P., Dwiyani, R., \& Sritamin, M. (2020). Morphometric variations of rasbora lateristriata bleeker population in different habitat: based on truss character analysis. International Journal of Life Sciences, 4(2), 9-18. https://doi.org/10.29332/ijls.v4n2.428 


\section{Conclusion}

The morphometric characters Rasbora lateristriata based on Truss network analysis found their closeness between the characters four fish populations Rasbora lateristriata namely the degree of similarity between populations that upstream populations similarity value is $100 \%$, branch is $60 \%$, middle is $75 \%$ and $75 \%$ in downstream (Sajina et al., 2011; Mohaddasi et al., 2013; Sen et al., 2011). Morphometric similarity value Rasbora lateristriata in the Sungi river area of $77.5 \%$, with a value of approximately $80 \%$ that have the same shape of fish Rasbora lateristriata on a branch, middle, and downstream, while upstream groups do not have an equal shape with the other. Morphometric character is influenced by the quality of water has exceeded the quality standard that is the temperature, $\mathrm{pH}$, Phosphate, Ammonia, Nitrate, BOD, COD and TSS so as the process of Rasbora lateristriata adaptation to environmental changes.

\section{Acknowledgments}

Our deep and sincere gratitude were presented to God for having granted us the ability and the opportunity to complete this paper. As well as, we have much appreciated to our friends for their support, suggestions, contribution in finishing this research. I would like thanking the editor that has given us a good advisement 


\section{References}

Ahmad, M., \& Nofrizal, N. (2011). Pemijahan dan Penjinakan Ikan Pantau (Rasbora Latestriata). Jurnal Perikanan dan Kelautan, 16(01), 71-78. http://dx.doi.org/10.31258/jpk.16.01.\%25p

Ayala, D., Caro-Riaño, H., Dujardin, J. P., Rahola, N., Simard, F., \& Fontenille, D. (2011). Chromosomal and environmental determinants of morphometric variation in natural populations of the malaria vector Anopheles funestus in Cameroon. Infection, Genetics and Evolution, 11(5), 940-947. https://doi.org/10.1016/j.meegid.2011.03.003

BLH Prov. Bali. 2009. Status Lingkungan Hidup Daerah Provinsi Bali. Denpasar.

Dina, R., Boer, M., \& Butet, N. A. (2011). Profil ukuran panjang dan tingkat kematangan gonad ikan bada (Rasbora argyrotaenia) pada alat tangkap berbeda di danau Maninjau. Oseanologi dan Limnologi di Indonesia, 37(1), 105118.

Garat, W., Corn, S., Le Moigne, N., Beaugrand, J., \& Bergeret, A. (2018). Analysis of the morphometric variations in natural fibres by automated laser scanning: towards an efficient and reliable assessment of the cross-sectional area. Composites Part A: Applied Science and Manufacturing, 108, 114-123. https://doi.org/10.1016/j.compositesa.2018.02.018

Hossain, M. D., Musa, M. H., Talib, J., \& Jol, H. (2010). Effects of nitrogen, phosphorus and potassium levels on kenaf (Hibiscus cannabinus L.) growth and photosynthesis under nutrient solution. Journal of Agricultural Science, 2(2), 49-57.

Kantor Lingkungan Hidup Kab. Tabanan. 2010. Status Lingkungan Hidup Daerah Kab, Tabanan. Tabanan.

Kusuma, W. E., Ratmuangkhwang, S., \& Kumazawa, Y. (2016). Molecular phylogeny and historical biogeography of the Indonesian freshwater fish Rasbora lateristriata species complex (Actinopterygii: Cyprinidae): cryptic species and west-to-east divergences. Molecular phylogenetics and evolution, 105, 212-223. https://doi.org/10.1016/j.ympev.2016.08.014

Mohaddasi, M., Shabanipour, N., \& Abdolmaleki, S. (2013). Morphometric variation among four populations of Shemaya (Alburnus chalcoides) in the south of Caspian Sea using truss network. The Journal of Basic \& Applied Zoology, 66(2), 87-92. https://doi.org/10.1016/j.jobaz.2013.09.001

Mundry, R., \& Sommer, C. (2007). Discriminant function analysis with nonindependent data: consequences and an alternative. Animal Behaviour, 74(4), 965-976. https://doi.org/10.1016/j.anbehav.2006.12.028

Patil, K. R., \& Mody, R. N. (2005). Determination of sex by discriminant function analysis and stature by regression analysis: a lateral cephalometric study. Forensic science international, 147(2-3), 175-180. https://doi.org/10.1016/j.forsciint.2004.09.071

Peralta, G., Brun, F. G., Hernández, I., Vergara, J. J., \& Pérez-Lloréns, J. L. (2005). Morphometric variations as acclimation mechanisms in Zostera noltii beds. Estuarine, Coastal and Shelf Science, 64(2-3), 347-356. https://doi.org/10.1016/j.ecss.2005.02.027

Roser, B. P., \& Korsch, R. J. (1988). Provenance signatures of sandstone-mudstone suites determined using discriminant function analysis of major-element data. Chemical geology, 67(1-2), 119-139. https://doi.org/10.1016/0009-2541(88)90010-1

Sajina, A. M., Chakraborty, S. K., Jaiswar, A. K., Pazhayamadam, D. G., \& Sudheesan, D. (2011). Stock structure analysis of Megalaspis cordyla (Linnaeus, 1758) along the Indian coast based on truss network analysis. Fisheries Research, 108(1), 100-105. https://doi.org/10.1016/j.fishres.2010.12.006

Sen, S., Jahageerdar, S., Jaiswar, A. K., Chakraborty, S. K., Sajina, A. M., \& Dash, G. R. (2011). Stock structure analysis of Decapterus russelli (Ruppell, 1830) from east and west coast of India using truss network analysis. Fisheries research, 112(1-2), 38-43. https://doi.org/10.1016/j.fishres.2011.08.008

Setiari, I. M., Mahendra, M. S., \& Suyasa, W. (2012). Identifikasi Sumber Pencemar Dan Analisis Kualitas Air Tukad Yeh Sungai Di Kabupaten Tabanan Dengan Metode Indeks Pencemaran. Jurnal Ilmu Lingkungan, 7(1), 40-16.

Sidik, S. M., Huet, D., Ganesan, S. M., Huynh, M. H., Wang, T., Nasamu, A. S., ... \& Lourido, S. (2016). A genomewide CRISPR screen in Toxoplasma identifies essential apicomplexan genes. Cell, 166(6), 1423-1435.

Simon, S. B., \& Hidayat, R. (2008). Pengendalian Pencemaran Sumber Air Dengan Ekoteknologi (Wetland Buatan). Jurnal Sumber Daya Air, 4, 111-124.

Solomon, A., Polvani, L. M., Smith, K. L., \& Abernathey, R. P. (2015). The impact of ozone depleting substances on the circulation, temperature, and salinity of the Southern Ocean: An attribution study with CESM1 (WACCM). Geophysical Research Letters, 42(13), 5547-5555. https://doi.org/10.1002/2015GL064744

Suryani, S. A. M. P., Wirawan, I. G. P., Dwiyani, R., \& Sritamin, M. (2020). Morphometric variations of rasbora lateristriata bleeker population in different habitat: based on truss character analysis. International Journal of Life Sciences, 4(2), 9-18. https://doi.org/10.29332/ijls.v4n2.428 
Suryani, S. A. M. P., Arya, I. W., \& Kawan, I. M. (2019, December). Longitudinal distribution and population structure Rasbora lateristriata bleeker, 1854 (osteichthyes: cyprinidae) in Sungi River. In Journal of Physics: Conference Series (Vol. 1402, No. 3, p. 033064). IOP Publishing.

Townsend, D. W. (1980). Microstructural growth increments in some Antarctic fish otoliths. Cybium, 3(8), 17-22.

Vannote, RL, Minshall, GW, Cummins, KW, Sedell, JR, \& Cushing, CE (1980). The river continuum concept. Canadian journal of fisheries and aquatic sciences, 37 (1), 130-137. https://doi.org/10.1139/f80-017 


\section{Biography of Authors}

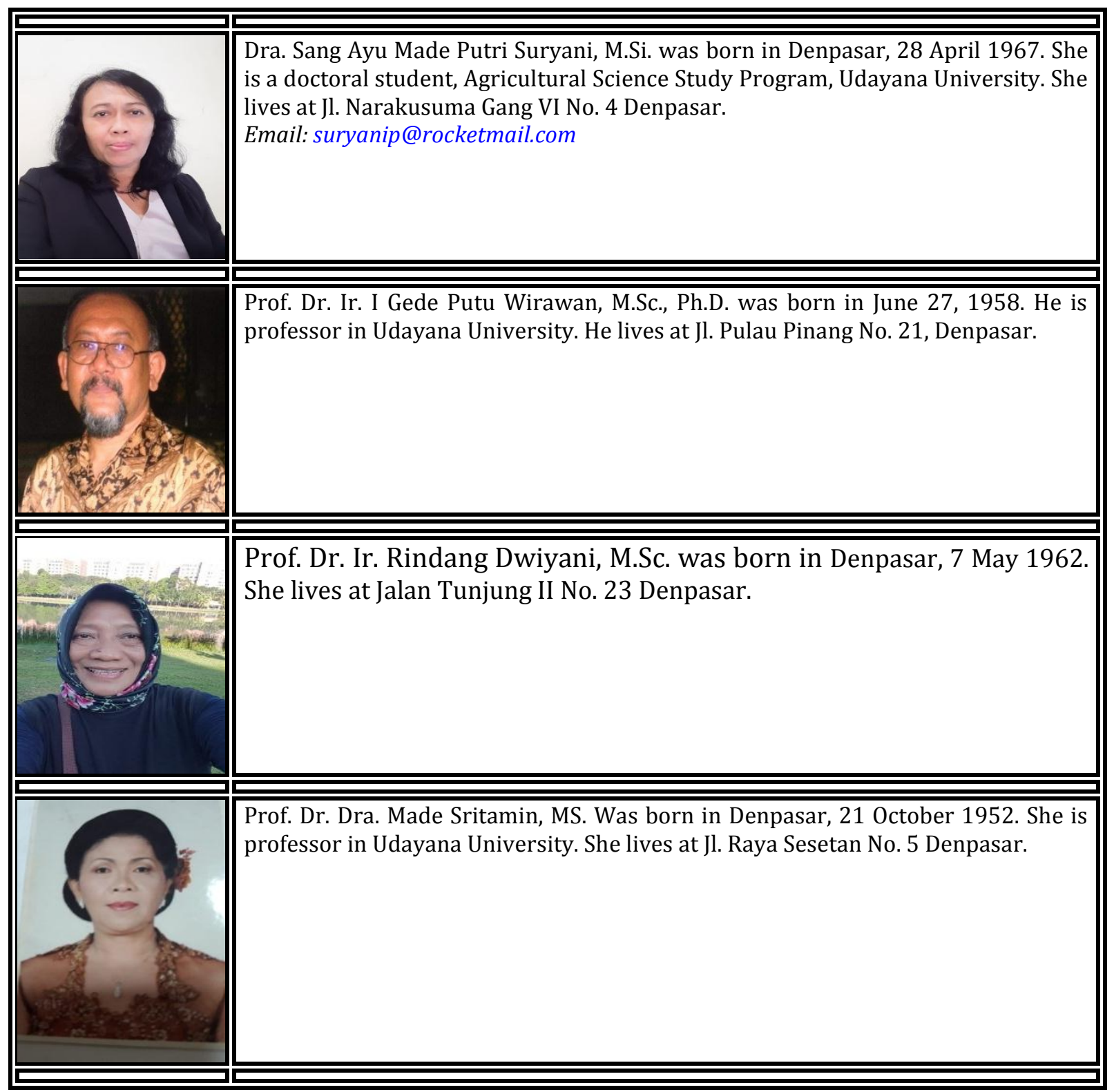

Suryani, S. A. M. P., Wirawan, I. G. P., Dwiyani, R., \& Sritamin, M. (2020). Morphometric variations of rasbora lateristriata bleeker population in different habitat: based on truss character analysis. International Journal of Life Sciences, 4(2), 9-18. https://doi.org/10.29332/ijls.v4n2.428 